\title{
The Mikulino (= Eemian) mammal faunas of the Russian Plain and Crimea
}

\author{
A.K. Markova ${ }^{1}$ \\ ${ }^{1}$ Institute of Geography RAS, Staromonetny 29, MOSCOW 109017, Russia; \\ e-mail: nature@glas.spc.org
}

Received: 12 December 1998; accepted in revised form: 18 February 2000

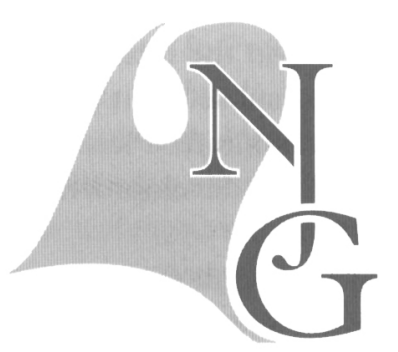

\begin{abstract}
During the last decades a considerable amount of data on mammals from Mikulino (=Eemian) deposits of the central and southern parts of the Russian Plain has been produced. Mammuthus primigenius (the early type), Palaeoloxodon antiquus (the advanced form), Arvicola ex gr. terrestris, Eolagurus cf. luteus and Lagurus cf. lagurus characterize this period. The so-called 'Shkurlatian mammal assemblage' was distinguished on the basis of a number of Eemian faunas.

The age of the mammal localities was established by using various geological and palaeontological evidence, together with the results of palaeomagnetic studies and absolute dating. The evolutionary level of the diagnostic species allows correlations between localities from different parts of the Russian Plain that have varying taphonomical conditions. The mammal- and malacofauna of the Mikulino Interglacial can also be used as a basis for correlations between the Karangat marine strata of the Black Sea and the continental deposits (alluvial sediments of the second terrace of the Sudost' River and the Salyn phase of the Mezin fossil pedocomplex (see Dodonov et al., this volume). Forest, forest-steppe and steppe zone landscapes have been reconstructed for the central and southern parts of the Russian Plain on the basis of the Eemian faunas.
\end{abstract}

Keywords: Crimea, Eemian, mammals, Mikulino, Russian Plain

\section{Introduction}

Mammal faunas of the last interglacial have been studied in Eastern Europe for about thirty years (see, among others, David \& Lungu, 1972; Markova, 1975, 1986; Alexeeva, 1980; Agadjanian \& Erbaeva, 1983; Kalinovski, 1983; Motuzko, 1985; Agadjanian \& Glushankova, 1986; Markova \& Milkhailesku, 1990; Dodonov et al., 1998). Mammal-bearing sites dating from the Mikulino (= Eemian, Muravino or Merkine) are rather scarce on the Russian Plain; only three localities with large mammal remains and twelve sites with small mammal bones have been found so far. Large mammal records were discovered in the Shkurlat locality (Don River basin), the Karagash locality (the North-western coast of the Black Sea), and the Zaskal'naia IX Palaeolithic site (lower layer in the Crimea). The mammal localities are located between $58^{\circ} \mathrm{NL}$ and $45^{\circ} \mathrm{NL}$ (Fig. 1). The so-called 'Shkurlatian mammal assemblage' was described on the basis of the Shkurlat mammal fauna Alexeeva, 1980; Markova, 1986).

\section{Geographical position, geological context, tapho- nomy and dating of the localities}

Mammal bones have been found in alluvial, marshy and marl deposits, in tufa, in cultural layers of Palaeolithic sites and also in so-called crotovines (burrows) in buried soils. The ages of these finds have been obtained primarily by using geological and palaeontological (theriological, palynological, carpological and malacological) methods. In a few cases, absolute dates have been obtained by using radiometric (UTh), OSL (optically stimulated luminescence) and ESR (electron spin resonance) methods. 


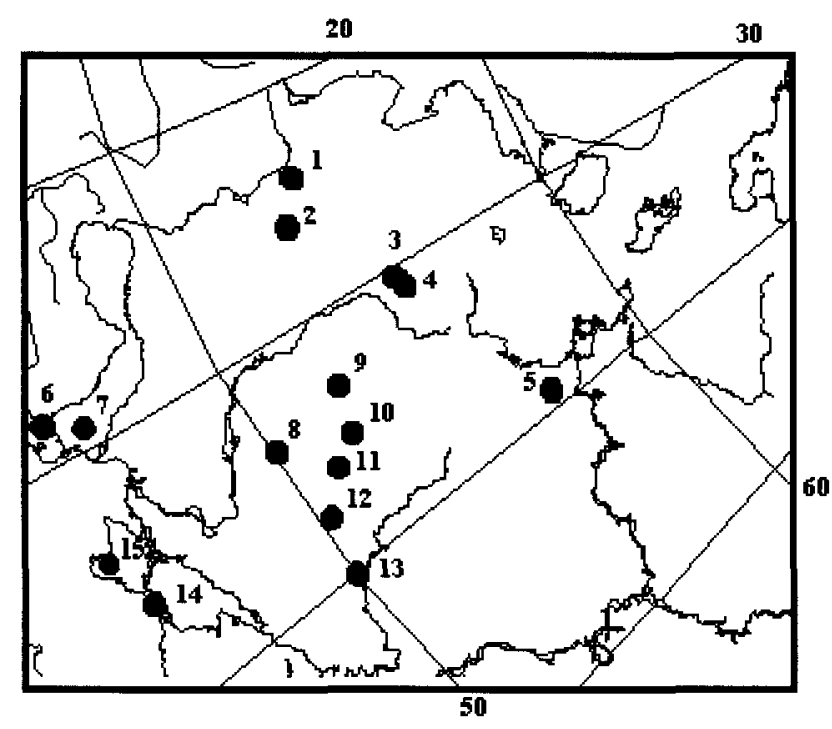

Fig. 1. Mammal localities of the Mikulino interglacial.

1 = Netiesos; 2 = Timoshkovichi; 3 = Borisova Gora; $4=$ Konevich; 5 = Cheremoshnik; $6=$ Novonekrasovka; 7 = Karagash; $8=$ Gadiach; 9 = Posudichi; $10=$ Mikhailovka 5; $11=-$ Malutino; 12 = Chernianka; 13 = Shkurlat; $14=$ El'tigen; 15 = Zaskal'naya IX (lower layer).

\section{Localities in alluvial deposits}

The Shkurlat locality (in the middle basin of the Don river) is the stratotype of the Mikulino interglacial mammal fauna. The geology of the complex Shkurlat section was studied by Shevyrev et al. (1987). Geologically, the mammal locality is associated with the alluvial deposits of a tributary of the Don. Shevyrev et al. correlate these deposits with the third terrace of the Don, but the sequence in this section has been complicated by tectonic interference. The Shkurlat alluvial deposits have yielded the typical Mikulino (= Eemian) interglacial flora that was described by Spiridonova, who recognised five palynological zones (Shevyrev et al., 1987). Alexeeva (1980) identified the large mammals of 'the Shkurlatian faunal complex', which include Mammuthus primigenius (early type), Palaeoloxodon antiquus (advanced type), Coelodonta antiquitatis and others (Table 1). The morphology of the Palaeoloxodon antiquus remains closely resembles that of $P$ antiquus germanicus from Weimar-Ehringsdorf and Taubach (Germany), correlated with the first part of the Eemian (Kahlke, 1975). The Shkurlat locality yielded ten different small mammal species (Table 2) (Markova, 1986).

Other faunal localities in fluvial deposits are Karagash (Dniester basin), Chernianka (Oskol river basin), Malutino (Seim river basin), Konevich (Dniepr basin) and Posudichi (Dniepr basin). These sites are in alluvial deposits of the second terrace (David \& Lungu, 1972; Kalinovski, 1981, 1983; Motuzko, 1985; Agadjanian \& Glushankova, 1986a;
Markova, 1986; Adamenko et al., 1996). The Posudichi fossiliferous bed corresponds to the lower part of the channel deposits in the second terrace of the Sudost' river and overlies the lacustrine deposits containing the typical Mikulino palynological sequence (Gurtovaya \& Faustova, 1977). This locality represents the end of the Mikulino interglacial (Agadjanian \& Glushankova, 1986b).

\section{Localities in tufa}

The Borisova Gora locality (in the Zapadnaya Dvina Basin) was found in the tufa that overlies the Dniepr till. The Middle Valdai solifluction deposits and the Valdai till rest on these travertines (San'ko \& Motuzko, 1991). According to San'ko and Motuzko, this locality represents the beginning of the Mikulino interglacial.

\section{Localities in lacustrine and bog deposits}

Among the localities of this type, the Timoshkovichi and Netiesos sites (Nemunus Basin) and the Cheremoshnik locality (the Rostov Lowland) date from the Mikulino (= Merkine) stage. ESR dates have been obtained from the Netiesos sequence: the lower samples gave $112 \pm 25 \mathrm{ka}$, and the upper samples $101.5 \pm$ $11.5 \mathrm{ka}$ (Gaigalas \& Molod'kov, 1997). The Netiesos lake deposits also have OSL dates of $95 \pm 12 \mathrm{ka}$ and $86 \pm 7 \mathrm{ka}$ for the lower bed, and $70 \pm 3 \mathrm{ka}$ and $70 \pm 8$ ka for the upper part (Gaigalas \& Hutt, 1997). In the Timoshkovichi site, the Mikulino (= Muravino) peats are overlain by Valdai-age glacial deposits. The peats yield typical Mikulino pollen spectra, as well as a warm interglacial insect fauna (Kalinovski, 1983; Nazarov, 1986).

The Netiesos locality includes a peat lens (containing a rich Mikulino-age seed and pollen flora) overlain by alluvial channel deposits that reach up to 12$13 \mathrm{~m}$ thick (Velichkevich, 1982).

The Cheremoshnik small mammal fauna was recovered from the Mikulino peat deposits of the Rostov Lowland. The fossiliferous bed is overlain by a Middle Pleistocene till unit. Rich plant remains (pollen and seeds) were found in the peat and described as being of typical Mikulino character (Grichuk, 1989). Cold, Valdai-age small-mammal faunal remains have been found in deposits overlying the peat (Agadjanian \& Erbaeva, 1983).

\section{Localities in fossil soils}

The Gadiach fauna (in the Psel river basin) was recovered from 'crotovines' within the Mezin pedocom- 
Table 1. Species composition of the mammals from the Mikulino localities.

\begin{tabular}{|c|c|c|c|c|c|c|c|c|c|c|c|c|c|c|c|}
\hline \multirow[t]{2}{*}{ Species } & \multicolumn{15}{|c|}{ Localities } \\
\hline & 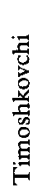 & 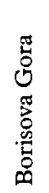 & $\begin{array}{l}\frac{1}{y} \\
\frac{0}{0} \\
0 \\
0 \\
0\end{array}$ & 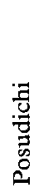 & 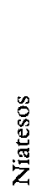 & 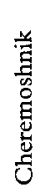 & $\frac{9}{\stackrel{\Xi}{\Xi}}$ & 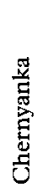 & 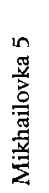 & 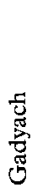 & 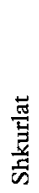 & 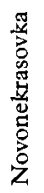 & 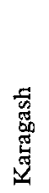 & 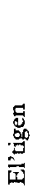 & 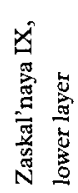 \\
\hline
\end{tabular}

\section{Insectivora:}

Erinaceus sp.

Talpa cf. europaea Linnaeus $\quad 7$

Sorex araneus Linnaeus 6

Sorex caecutiens Laxmann 2

Sorex minutus Linnaeus $\quad 2$

Sorex isodon Turov

Sorex sp.

Neomys fodiens Pennant

2

Desmana moschata Linnaeus 1

1

\section{Lagomorpha:}

Lepus sp.

Ochotona pusilla Pallas

16

19

1

8

\section{Rodentia:}

Sciurus vulgaris Linnaeus.

2

Marmota bobac Muller

Marmota sp.

Spermophilus cf. suslicus

Guldenstaedt

Spermophilus sp.

Allactaga major Pallas

Allactaga sp.

Pygeretmus (Alactagulus)

acontion Kerr

Spalax microphtalmus

Guldenstaedt

Castor sp.

Cricetulus migratorius Pallas

Cricetus cricetus Pallas

Glis sp.

Apodernus (Sylvimus)

flavicollis Melchior

Apodemus ex gr.

sylvaticus-flavicollis

Mus musculus Linnaeus

Lemmus sibiricus Kerr

Myopus vel Lemmus

Dicrostonyx sp.

Ellobius talpinus Pallas

Clethrionomys glareolus

Schreber

Eolagurus cf. luteus

Eversmann

Lagurus aff. lagurus Pallas

Arvicola ex gr. terrestris

Linnaeus

86

Microtus (Terricola)

subterraneus

Selys-Longchamps

Microtus (Stenocranius)

gregalis Pallas

Microtus (Microtus)

agrestis Linnaeus

Geologie en Mijnbouw / Netherlands Journal of Geosciences 79(2/3) 2000 
Table 1. Continued.

\begin{tabular}{|c|c|c|c|c|c|c|c|c|c|c|c|c|c|c|c|}
\hline \multirow[t]{2}{*}{ Species } & \multicolumn{14}{|c|}{ Localities } & \multirow[b]{2}{*}{ 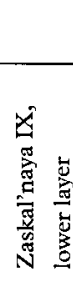 } \\
\hline & 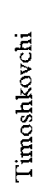 & 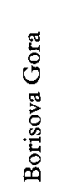 & 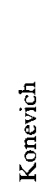 & 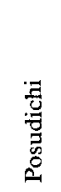 & 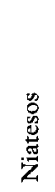 & 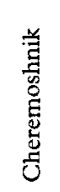 & 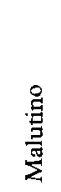 & 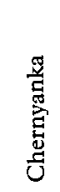 & 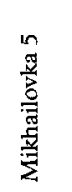 & 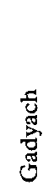 & 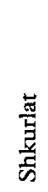 & 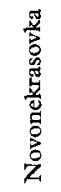 & 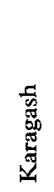 & 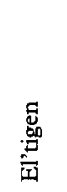 & \\
\hline \multicolumn{16}{|l|}{ Microtus (Microtus) } \\
\hline arvalis Pallas & 1 & 4 & & & 9 & 1 & 2 & 1 & 8 & & 1 & 9 & & & \\
\hline Microtus obscurus Eversmann & & & & & & & & & & & & & & 210 & \\
\hline \multicolumn{16}{|l|}{ Microtus (Pallasiinus) } \\
\hline oeconomus Pallas & & 3 & 3 & & & 2 & 15 & 2 & & & 2 & & & & \\
\hline Microtus sp. & 6 & 154 & 9 & 13 & & 47 & 34 & 47 & 132 & 13 & 52 & 8 & & & \\
\hline \multicolumn{16}{|l|}{ Carnivora: } \\
\hline Ursus sp. & & 1 & & & & & & & & & & & & & \\
\hline Canis lupus Linnaeus & & & & & & & & & & & & & & & 6 \\
\hline Vulpes vulpes Linnaeus & & 1 & & & & & & & & & & & & & 9 \\
\hline Vulpes corsak Linnaeus & & & & & & & & & & & & & & & 5 \\
\hline \multicolumn{16}{|l|}{ Crocuta (Crocuta) spelaea } \\
\hline Godfuss & & & & & & & & & & & & & & & 1 \\
\hline \multicolumn{16}{|l|}{ Panthera (Leo) spelaea } \\
\hline Goldfuss & & & & & & & & & & & + & & & & \\
\hline \multicolumn{16}{|l|}{ Proboscidea: } \\
\hline \multicolumn{16}{|l|}{ Mammuthus primigenius } \\
\hline Blumenbach (early type) & & & & & & & & & & & + & & + & & \\
\hline \multicolumn{16}{|l|}{ Palaeoloxodon antiquus } \\
\hline \multicolumn{16}{|l|}{ Falconer et Cautley } \\
\hline (advanced type) & & & & & & & & & & & + & & + & & \\
\hline \multicolumn{16}{|l|}{ Perissodactyla: } \\
\hline \multicolumn{16}{|l|}{ Equus ex gr. } \\
\hline caballus Linnaeus & & & & & & & & & & & + & & & & 1 \\
\hline \multicolumn{16}{|l|}{ Coelodonta antiquitatis } \\
\hline Blumenbach & & & & & & & & & & & + & & & & \\
\hline \multicolumn{16}{|l|}{ Artiodactyla: } \\
\hline Sus sp. & & 1 & & & & & & & & & & & & & \\
\hline Bison priscus Bojanus & & & & & & & & & & & + & & & & 1 \\
\hline Bos trochoceros Meyer & & & & & & & & & & & & & + & & \\
\hline Cervus elaphus Linnaeus & & 3 & & & & & & & & & & & + & & \\
\hline Saiga tatarica Linnaeus & & & & & & & & & & & & & & & 29 \\
\hline
\end{tabular}

plex formed during the Mikulino interglacial. In the Gadiach section, the Mezin soil, overlain by a Valdaiage loess series, rests on top of the Dniepr Till (Markova, 1986).

The Michailovka 5 locality (Svapa river basin) was found in remnants of the Mezin fossil soil, which overlies Dniepr fluvioglacial sediments and is overlain by Valdai periglacial deposits (Agadjanian \& Glushankova, 1986b).

\section{Localities in calcareous deposits}

The Novonekrasovka (the lower Danube basin) and the El'tigen (Crimea, the Kerch' peninsula) sites were found in the Karangat (= Eemian) coquina, together with a rich mollusc fauna, associated with the Karangat transgression of the Black Sea. Palaeomagnetic studies of the El'tigen section allows identification of the Blake Event in the fossiliferous strata. A few dates have also been obtained from these sediments by using the U-Th method: $127 \pm 8.9$ ka for cycle I, and $107 \pm 7.7 \mathrm{ka}$ for cycle II of this sequence (Markova \& Mikhailesku, 1990; Dodonov et al., 2000 - this issue). The fauna was recovered from cycle I deposits (substages $\mathrm{Ib}$ and Ic). 


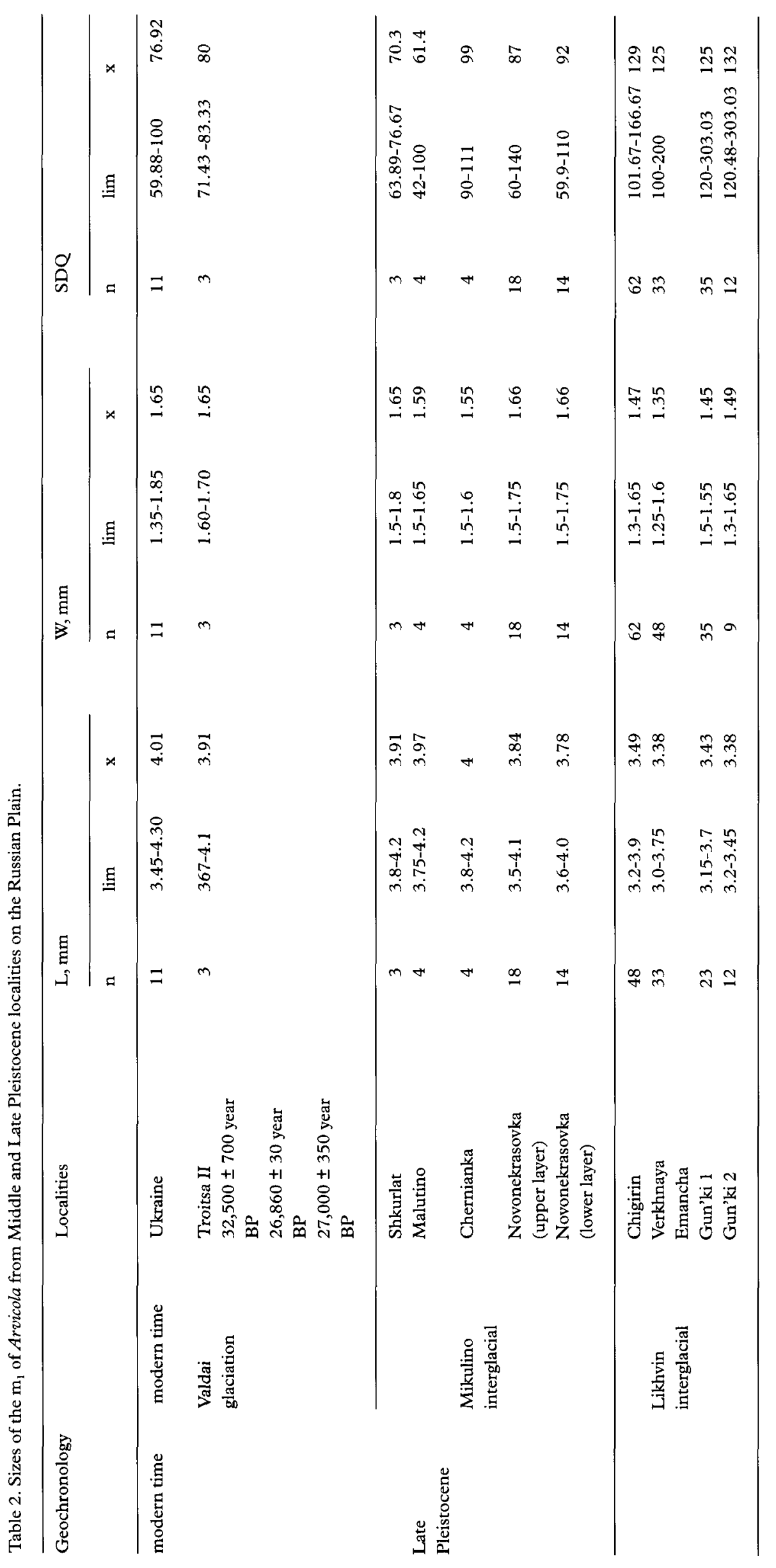


Table 3. Sizes of the $\mathrm{m} 1$ and the $\mathrm{A} / \mathrm{L}$ index of Lagurus cf. lagurus from Mikulino localities.

\begin{tabular}{|c|c|c|c|c|c|c|c|c|c|c|}
\hline \multirow[t]{2}{*}{ Localities } & \multicolumn{2}{|l|}{$\mathrm{L}, \mathrm{mm}$} & \multicolumn{2}{|l|}{$\mathrm{W}, \mathrm{mm}$} & \multicolumn{2}{|l|}{$\mathrm{L}$ of $\mathrm{ACC}, \mathrm{mm}$} & \multicolumn{2}{|l|}{$\mathrm{L}$ of $\mathrm{AC} 2, \mathrm{~mm}$} & \multicolumn{2}{|l|}{$\mathrm{A} / \mathrm{L}$} \\
\hline & $\lim$ & $\mathrm{n}$ & $\lim$ & $\mathrm{n}$ & $\lim$ & $\mathrm{n}$ & $\lim$ & $\mathrm{n}$ & $\lim$ & $\mathrm{n}$ \\
\hline Gadiach & $2.1-2.4-2.7$ & 3 & $0.85-0.9-0.95$ & 3 & $1.3-1.367-1.4$ & 3 & $0.7-0.733-0.75$ & 3 & $51-57-61$ & 3 \\
\hline Malutino & $2.1-2.434-2.75$ & 16 & $0.7-0.866-0.75$ & 16 & $1.15-1.368-1.6$ & 16 & $0.7-0.81-1.0$ & 16 & $54-56-58$ & 16 \\
\hline Chernianka & 2.35 & 1 & 0.85 & 1 & 1.25 & 1 & 0.75 & 1 & 53 & 1 \\
\hline Shkurlat & $2.2-2.491 .-2.8$ & 35 & $0.6-0.845-1.05$ & 35 & $1.15-1.329-1.6$ & 35 & $0.7-0.798-0.9$ & 35 & $52-53-57$ & 35 \\
\hline
\end{tabular}

Table 4. Morphotypes of the $\mathrm{m} 1$ Lagurus from Middle and Late Pleistocene localities on the Russian Plain.

\begin{tabular}{|c|c|c|c|c|c|c|c|}
\hline \multirow[t]{3}{*}{ Geochronology } & \multirow{3}{*}{$\begin{array}{l}\text { Mammal } \\
\text { assemblages }\end{array}$} & \multirow[t]{3}{*}{ Species } & \multirow[t]{3}{*}{ Localities } & \multicolumn{4}{|c|}{ Morphotypes of ACC of $\mathrm{m} 1, \%$} \\
\hline & & & & \multicolumn{2}{|c|}{ 'transiens' } & \multicolumn{2}{|c|}{ 'agurus' } \\
\hline & & & & $\%$ & $\mathrm{n}$ & $\%$ & $\mathrm{n}$ \\
\hline \multirow[t]{4}{*}{ Valdai glaciation } & Mammoth & & Luchki & - & - & 100 & 4 \\
\hline & & $\begin{array}{l}\text { Lagurus aff. } \\
\text { lagurus }\end{array}$ & & & & & \\
\hline & & & Arapovichi & 11.12 & 2 & 88.88 & 16 \\
\hline & & & Gadiach & 33.33 & 1 & 66.676 & 2 \\
\hline \multirow{2}{*}{$\begin{array}{l}\text { Mikulino } \\
\text { interglacial }\end{array}$} & Shkurlatian & & Chernianka & - & - & 100 & 1 \\
\hline & & & Shkurlat & 17.24 & 5 & 82.76 & 24 \\
\hline
\end{tabular}

Dnieper

glaciation

Lagurus ex

Romny Khozarian gr. lagurus

warming

cooling

(glaciation)

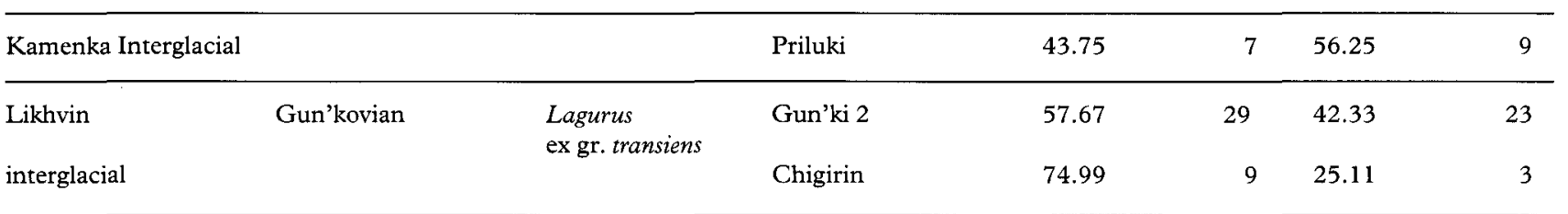

Faunas from cultural layers of Palaeolithic sites

Mammalian remains have been collected from the lower cultural layer at the Zaskal'naya IX Palaeolithic site (grotto on the Ak-Kaya plateau, Crimea). From this site, Mousterian artefacts of an archaic type were described from the lower layer (Kolosov, 1986; Kolosov et al., 1993). Remains of mammoths and arctic foxes have not been discovered here, although they are very typical of other Mousterian sites in the Crimea. Both the archaeological data and the mammal fauna therefore unambiguously indicate that the lower layer at $\mathrm{Za}$ skal'naya IX is one of the earliest Mousterian sites in the Crimea and that it might be correlated with a warm interglacial event (Kolosov, 1986).

\section{The mammalian faunas}

\section{Small mammals ${ }^{1}$}

Arvicola ex gr. terrestris Linnaeus - water vole Arvicola teeth from Mikulino localities show the following morphological characteristics (Table 2):

\footnotetext{
1 Terminology: in the present contribution, the following terminology - introduced by Van der Meulen (1973) - was used for the part of the occlusal surface of molars of voles. $\mathrm{L}=$ the length of molars; $\mathrm{W}=$ the width of molars; $\mathrm{AC} 2=$ the anterior cap; $\mathrm{ACC}=$ the anteroconid complex; $A=$ the length of anteroconid complex;T1-T5 $=$ the dentine fields of occlusal surface of molars; $\mathrm{B}=$ the shortest distance between $\mathrm{AC} 2$ and $\mathrm{T} 4$ and $\mathrm{T} 5$; BRA $=$ the buccal re-entrant angle; LRA = the lingual re-entrant angle; $\mathrm{C}=$ the shortest distance between the BRA 3 and the LRA 3 angles. We also used the SDQ index after Heinrich (1978), which shows the ratio between the thickness of the enamel on the posterior wall of the molar salient angles and the thickness of the enamel on the anterior part of the salient angles. In th we used the measurements of the enamel of three central angles of the $\mathrm{ml}$ (LSA2, LSA3, BSA2).
} 
(1) the teeth of the Mikulino water voles are smaller than those of modern representatives, but larger than those of the late Middle Pleistocene water voles;

(2) the SDQ index shows a positive enamel differentiation of the molars, but the enamel is less differentiated than the enamel of the modern Arvicola teeth.

Judging from the complex of morphological characteristics, the water vole remains from Mikulino sites are closer to those of $A$. terrestris than to those of $A$. cantianus and may be attributed to Arvicola ex gr. terrestris.

\section{Lagurus cf. lagurus Pallas - steppe lemming}

The sizes of the $\mathrm{ml}$ do not differ significantly from those of the modern Lagurus lagurus. Differences are more pronounced when comparing them with samples from earlier localities (Table 3). The 'lagurus' morphotypes of the $\mathrm{m} 1$ and the $\mathrm{M} 3$ dominate in the populations of this age and reach $70 \%$ and even more. The 'transiens' morphotypes persist at very low proportions (Table 4).

Eolagurus cf. luteus Eversmann - yellow steppe lemming The sizes of Mikulino Eolagurus teeth (Table 5) are a bit smaller than modern ones, but larger than Middle and Early Pleistocene ones. Dentine fields of $\mathrm{ml}$ and M3 of Mikulino yellow steppe lemmings are not completely separated. ACC characteristics show a rather low differentiation. The tooth size and the coefficient showing the degree of confluence between the angles at the base of anteroconid are most diagnostic (Table. 5).

Microtus (Stenocranius) gregalis - narrow-skulled vole The typical 'gregalis' morphotypes of the ACC dominate over the 'arvalis'-like morphotypes, which are more characteristic of the Valdai glacial faunas (Table 6). T4 and T5 are practically separated. AC 2 is also separated from $\mathrm{T} 4$ and $\mathrm{T} 5$.

\section{Large mammals}

The Mikulino localities of the Russian Plain are char-

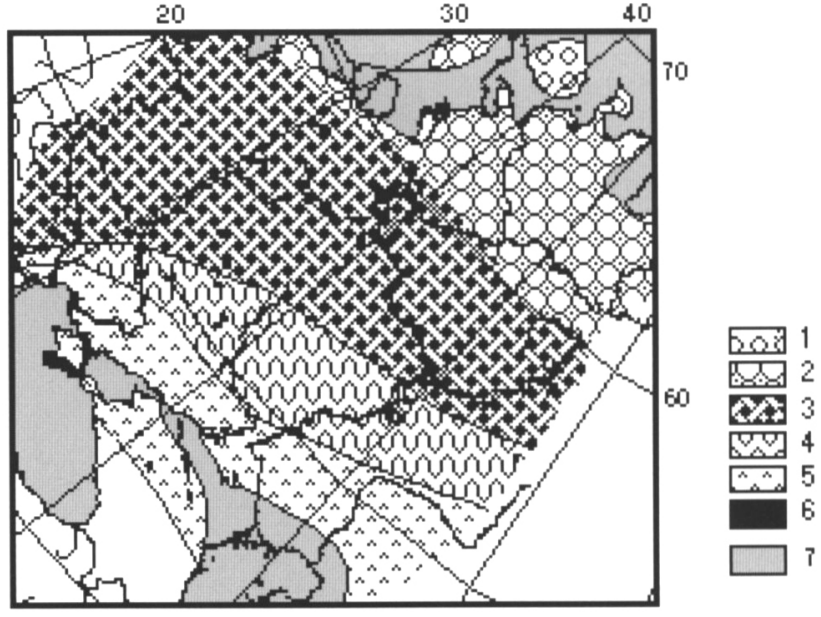

Fig. 2. Vegetation types and types of mammal communities during the Mikulino interglacial.

$1=$ birch and pine open woodland (after Grichuk, 1989), no mammal finds; $2=$ the fir $/$ birch woodland with some oak and hornbeam in the South (after Grichuk, 1989), no mammal finds; 3 = mammal community of mixed and broad-leaved woodland; $4=$ forest $/$ steppe mammal community; $5=$ steppe mammal community; $6=$ mountain-steppe mammal community; 7 = sea basins.

acterised by the presence of remnants of Mammuthus primigenius (early type), Palaeoloxodon antiquus (advanced type), Coelodonta antiquitatis, Bison priscus, Bos trochoceros and two cave carnivores, Panthera (Leo) spelaea and Crocuta spelaea. The bone morphology of other species of carnivores (Ursus arctos, Vulpes vulpes and $V$. corsak) does not differ from that of modern species (Alexeeva, 1980; David \& Lungu, 1972).

\section{Mammal communities}

The characteristics of the Mikulino fauna have been inferred primarily from small mammal assemblages (only three sites have yielded larger mammal remains). All localities are concentrated in the central and southern parts of the Russian Plain and on the Crimea peninsula. No mammal localities of Mikulino age have been found north of $60^{\circ} \mathrm{NL}$.

Table 5. Sizes of fossil and modern Eolagurus.

\begin{tabular}{|c|c|c|c|c|c|c|c|c|c|}
\hline \multirow[t]{2}{*}{ Geochronology } & \multirow[t]{2}{*}{ Localities } & \multirow[t]{2}{*}{$\mathrm{n}$} & \multicolumn{2}{|c|}{$\mathrm{L} \mathrm{m}_{1}(\mathrm{~mm})$} & \multicolumn{2}{|l|}{$\mathrm{B} / \mathrm{L}$} & \multicolumn{2}{|l|}{$\mathrm{C} / \mathrm{L}$} & \multirow[t]{2}{*}{ Species } \\
\hline & & & $\mathbf{x}$ & $\mathrm{m}_{\mathrm{r}}$ & $\mathrm{x}$ & $\mathrm{m}_{\mathrm{r}}$ & $\mathrm{x}$ & $\mathrm{m}_{\mathrm{H}}$ & \\
\hline Valdai glaciation & Malyi Gai & 3 & 3.15 & \pm 0.126 & 1.67 & \pm 0.086 & 1.6 & \pm 0.19 & Eolagurus aff.luteus \\
\hline \multirow{2}{*}{ Mikulino interglacial } & Shkurlat & 8 & 3.05 & \pm 0.082 & 1.67 & \pm 0.12 & 1.7 & \pm 0.23 & \\
\hline & Malutino & 2 & 3.075 & \pm 0.2704 & 2.275 & \pm 0.6008 & 2.90 & \pm 0.4422 & \\
\hline \multirow[t]{2}{*}{ Likhvin interglacial } & Gun'ki II & 17 & 2.92 & \pm 0.0411 & 2.9 & \pm 0.29 & 3.2 & \pm 0.26 & Eolagurus \\
\hline & Chigirin & 13 & 2.95 & \pm 0.0302 & 2.66 & \pm 0.97 & 3.5 & \pm 0.87 & luteus volgensis \\
\hline \multirow[t]{2}{*}{ early Middle Pleistocene } & Tikhonovka & 12 & 3.025 & \pm 0.0279 & 2.85 & \pm 0.4961 & 5.86 & \pm 0.6374 & Eolagurus gromovi \\
\hline & Platovo & 7 & 3.025 & \pm 0.0279 & 2.85 & \pm 0.4961 & 5.86 & \pm 0.6374 & \\
\hline end of Early Pleistocene & Karai-Dubina & 35 & 2.77 & \pm 0.02237 & 2.9 & \pm 0.188 & 7.03 & \pm 0.187 & $\begin{array}{l}\text { Eolagurus } \\
\text { cf. argyropuloi }\end{array}$ \\
\hline
\end{tabular}


Table 6. Measurements and $\mathrm{A} / \mathrm{L}$ index of the $\mathrm{m} 1$ of the Microtus (Stenocranius) lineage.

\begin{tabular}{|c|c|c|c|c|c|c|c|c|c|c|}
\hline \multirow[t]{2}{*}{ Geochronology } & \multirow[t]{2}{*}{ Localities } & \multirow[t]{2}{*}{ Species } & \multicolumn{4}{|c|}{$\mathbf{L} \mathrm{ml}, \mathrm{mm}$} & \multicolumn{4}{|c|}{$\mathrm{A} / \mathrm{L}$} \\
\hline & & & $\mathrm{n}$ & $\min$ & $\mathbf{x}$ & $\max$ & $\mathbf{n}$ & $\min$ & $\mathrm{x}$ & $\max$ \\
\hline Valdai glaciation & Khotylevo 2 & M. (S.) gregalis & 40 & 2.35 & 2.8 & 3 & 20 & 52 & 54.1 & 56.4 \\
\hline \multirow[t]{3}{*}{ Mikulino interglacial } & Malutino & M. (S.) gregalis & 20 & 2.35 & 2.7 & 3 & 17 & 50.9 & 54.1 & 56.5 \\
\hline & Shkurlat & M.(S.) gregalis & 22 & 2.25 & 2.6 & 2.95 & 10 & 49.6 & 52.2 & 55.7 \\
\hline & Chigirin & M. (S.) cf. gregalis & 24 & 2.35 & 2.7 & 3.1 & 10 & 48.4 & 51.9 & 54.4 \\
\hline Likhvin interglacial & Gun'ki 2 & $M .(S$.$) cf. gregalis$ & 61 & 2.25 & 2.6 & 2.75 & 25 & 47.9 & 51.5 & 53.9 \\
\hline Muchkap interglacial & $\begin{array}{l}\text { Suvorovo } \\
\text { (upper layer) }\end{array}$ & $\begin{array}{l}\text { M. (S.) gregalis - } \\
M .(S .) \text { gregaloides }\end{array}$ & 8 & 2.37 & 2.5 & 2.68 & 8 & 47.5 & 50.5 & 54.7 \\
\hline $\begin{array}{l}\text { very end of Early } \\
\text { Pleistocene }\end{array}$ & Karai-Dubina & M. (S.) hintoni & 90 & 2.2 & 2.5 & 2.8 & 23 & 44.3 & 47.3 & 50.6 \\
\hline
\end{tabular}

\section{Mixed and broad-leaved forest community}

Mammal communities dominated by forest species were distributed on the Russian Plain between $60-52^{\circ}$ $\mathrm{NL}$ and, possibly, even further north. Erinaceus europaeus, Sciurus vulgaris, Castor fiber, Apodemus, Clethrionomys glareolus, Microtus (Terricola) subterraneus and $M$. (Microtus) agrestis were widely distributed. This assemblage has been termed the 'mixed and broad-leaved forest community' (Figure 2). From the early phase of the Mikulino interglacial, a small number of cold-tolerant animal remains (Dicrostonyx sp.) were found in the Borisova Gora locality (Table 2). Lemmus sibiricus and Lemmus vel Myopus remains have also been discovered from sites located at $53-55^{\circ}$ $\mathrm{NL}$. The records of the fossil Lemmus remains may indicate less strict environmental requirements for this species during the Pleistocene (when they were also typical of boreal forests) than at present.

\section{Forest-steppe mammal community}

The distribution area of the so-called 'forest-steppe mammal community' was situated further south: south of $52^{\circ} \mathrm{NL}$. The steppe species (Ochotona pusilla, Spermophilus, Marmota bobac, Spalax microphtalmus, Ellobius talpinus, Cricetus cricetus, Cricetulus migratorius, Lagurus cf. lagurus, Eolagurus cf. luteus, Microtus (Stenocranius) gregalis), forest species (Clethrionomys glareolus, Microtus (Microtus) agrestis), meadow species (Microtus (Microtus) arvalis) and 'intra-zonal' species (Arvicola ex gr. terrestris, Microtus (Pallasiinus) oeconomus) occurred in this zone. The southern limit of this community was about $45^{\circ} \mathrm{NL}$ in the central part of the Russian Plain (Fig. 2).

\section{Steppe mammal community}

The 'steppe mammal community' existed in the Northern Black Sea coastal region and in the Crimea, where only steppe species lived during the Mikulino in- terglacial. The species included Ochotona pusilla, Spermophilus, Spalax, Sicista subtilis, Allactaga major, Ellobius talpinus, Lagurus, Eolagurus, Microtus (Stenocranius) gregalis, Microtus (Microtus) obscurus and others.

\section{Conclusions}

It is possible to reconstruct at least the following three biomes in the central and southern parts of the Russian Plain on the basis of mammal faunas from the Mikulino localities (unfortunately there are no records from the Northern part of Eastern Europe).

(1) The zone of mixed and broad-leaved forests with a rich fauna of forest mammals from $60^{\circ}$ to $52^{\circ}$ NL. The northern boundary of this zone was farther to the north during the Mikulino than at the present-day. The southern limit occurred close to the modern one.

(2) The southern forest/steppe zone, where high concentrations of steppe mammals (rodents, insectivores, lagomorphes, proboscidea, artiodactyla and perrisodactyla) were found. Several forest species also inhabited this region. The geographical position of this zone during Mikulino times resembles that at the present-day.

(3) The steppe zone into the extreme South of Eastern Europe. The steppe mammals (primarily small mammals) inhabited this region, not only during the Mikulino, but also during earlier warm intervals of the Middle Pleistocene (the Il'inka, Muchkap, Likhvin and Kamenka interglacials) and even during the Early Pleistocene (Markova, 1992). All this evidence demonstrates the antiquity of the steppe biome on the Russian Plain.

The East European Mikulino mammalian assemblages are not very rich, but as a whole they indicate warmer climatic conditions during this stage than today. The existence of a wider broad-leaved forest zone on the Russian Plain, with numerous forest mammals, supports this conclusion. 


\section{Acknowledgements}

The author thanks Dr. Thijs van Kolfschoten and Dr. Phil Gibbard for their suggestions. I also like to thank Dr. C. Mikhailesku and Dr. A. Dodonov for their assistance during field work at the Mikulino localities and Dr. N. Bolikhovskaya, Dr. I. Spasskaya, Dr. S. Sycheva and Dr. E. Gurtovaya for their recommendations concerning the literature.

\section{References}

Adamenko, O.M., Gol'bert, A.V., Osiniuk, V.A., Matviishina, Zh.A., Motok, V.E., Sirenko, N.A. \& Cherniuk, A.V., 1996. Quaternary paleogeography, ecosystems of Lower and Middle Dniester. Fenix Press (Kiev): 200 pp.

Agadjanian, A.K. \& Erbaeva, M.A., 1983. Late Cenozoic rodents and lagomorphes of the USSR territory [in Russian]. Nauka Press (Moscow): $187 \mathrm{pp}$.

Agadjanian, A.K. \& Glushankova, N.I., 1986a. Pleistocene of Desna basin [in Russian]. Moscow State University (Moscow): $227 \mathrm{pp}$.

Agadjanian, A.K. \& Glushankova, N.I., 1986b. Mikhailovka - the key Pleistocene section of Russian Plain [in Russian]. Moscow State University (Moscow): $163 \mathrm{pp}$.

Alexeeva, L.I., 1980. Peculiarities of mammals associations of the last interglacial at the Russian Plain [in Russian]. In: Mlekopitaiushchie Vostochnoi Evropy [Mammals of Eastern Europe]. Trudy Zoologicheskogo Instituta AN SSSR 93: 68-74.

David, A.I. \& Lungu, A.N., 1972. Mammal remains from Karagash quarry [in Russian]. In: Pozvonochnye Neogena i Pleistocena Moldavii [Neogene and Pleistocene vertebrates of Moldavia]. Shtiintsa Press (Kishinev): 19-24.

Dodonov, A.E., Trubikhin, V.M., Markova, A.K., Tchepalyga, A.L. \& Konikov, E.G., 1998. Last interglacial in transregional aspect: continental loess-palaeosol successions and marine deposits from Central Asia to the Black Sea shore. In: Abstract volume of the INQUA-SEQS Symposium 'The Eemian - local sequences, global perspectives': 20 .

Dodonov, A.E., Tchepalyga, A.L., Mikhailesku, C.D., Zhou, L.P., Markova, A.K., Trubikhin, V.M., Simakova, A.N. \& Konikov, E.G., 2000. The last-interglacial records from central Asia to the Northern Black Sea shore: stratigraphy and correlation. In: Van Kolfschoten, Th. \& Gibbard, P.L. (eds.): The Eemian - local sequences, global perspectives. Geologie en Mijnbouw / Netherlands Journal of Geosciences 79: 303-311 (this issue).

Gaigalas, A. \& Hutt, G., 1997. The OSL age of the lacustrine sand of Upper Pleistocene at the outcrop Netiesos. In: The Late Pleistocene in Eastern Europe: stratigraphy, palaeoenvironment and climate. Abstract volume and excursion guide of the INQUASEQS Symposium (Vilnius): 12.

Gaigalas, A. \& Molod'kov, A., 1997. New ESR dates of the Butenai and Merkine interglacial deposits in the Neravai and Netiesos exposures. In: The Late Pleistocene in Eastern Europe: stratigraphy, palaeoenvironment and climate. Abstract volume and excursion guide of the INQUA-SEQS Symposium (Vilnius):13.

Grichuk, V.P., 1989. The history of flora and vegetation of Russian Plain during Pleistocene [in Russian]. Nauka Press (Moscow): $182 \mathrm{pp}$.
Gurtovaya, E. E. \& Faustova, M.A., 1977. About the Mikulino stage of alluvium deposition in Middle Desna-River basin (on the example of Posudichi section)[in Russian]. Izvestia AN SSSR, Seria Geographicheskaia 2: 69-75.

Heinrich, W.-D., 1978. Zur biometrischen Erfassung eines Evolutionstrends bei Arvicola (Rodentia, Mammalia) aus dem Pleistozän Thüringens. Saugetierliche Mitteilungen 2: 3-21.

Kahlke H.-D., 1975. Zur chronologischen Stellung der Travertine von Weimar. Eringsdorfer Abhandlungen Zentr. Geologisches Institut (Berlin) 23: 591-596.

Kalinovski, P.F., 1981. About the first finds of Pleistocene rodents on the Litva territory [in Russian]. In: Geologicheskie issledovania Kainozoia Byelarussii [Geological studies of Cenozoic of Byelorussia]. Nauka i Tekhnika Press (Minsk): 134-139.

Kalinovski, P.F., 1983. Theriofauna of Late Pleistocene and Holocene of Belorussia [in Russian]. Nauka i Tekhnika Press (Minsk): 153 pp.

Kolosov, Yu.G., 1986. Akkai Musterian culture [in Russian]. Naukova Dumka Press (Kiev): 223 pp.

Kolosov, Yu.G., Stepanchuk, V.N. \& Chabai, V.P. 1993. Early Palaeolithic of Crimea [in Russian]. Naukova Dumka Press (Kiev): 222 pp.

Markova, A.K., 1975. The fossil rodents from the Mezin pedocomplex [in Russian]. Izvestia Akademii Nauk SSSR, Seria Geograficheskaya 5: 82-88.

Markova, A.K., 1986. The morphological features of teeth Arvicola, Lagurus, Eolagurus \& Microtus (Rodentia, Cricetidae) from the Mikulino localities of Russian Plain [in Russian]. Trudy Zoologicheskogo Instituta Akademii Nauk SSSR 149: 74-97.

Markova, A.K., 1992. The Pleistocene small mammals of Eastern Europe [in Russian]. In: Velichko, A. \& Shik, S. (eds.): Stratigraphy and paleogeography of the Quaternary of Eastern Europe. Institute of Geography RAS (Moscow): $50-94$.

Markova, A.K. \& Mikhailesku, C.D., 1990. The new locality of mammal and mollusc fauna in Mikulino deposits of Lower Danube basin [in Russian]. Bulleten' Komissii po izucheniu Chetvertichnogo perioda 59: 94-101.

Motuzko, A.N., 1985. Anthropogene rodents of Belorussia and adjacent territories [in Russian]. In: Problemy Pleistocena. Nauka i Tekhnika Press (Minsk): 173-188.

Nazarov, V.I., 1986. The new species of entomofauna of Mikulino Interglacial in Belorussia [in Belorussian]. In: Levkov, E.A. \& Yakubovskaya, T.V. (eds.): Novye i maloizvestnye vidy iskopaemykh zhivotnykh i rastenii Belorussii. Nauka i Tekhnika Press (Minsk): 167-171.

San'ko, A.F. \& Motuzko, A.N., 1991. Molluscs and mammals from calcareous tuffs of Borisova Gora on Zapadnaya Dvina [in Russian]. Doklady Akademii Nauk Belarusskoi Socialisticheskoi Respubliki, Geologia 35: 1004-1008.

Shevyrev, L.T., Alexeeva, L.I., Spiridonova, E.A., Tikhomirov, S.V., Arslanov, X.A., Gei, N.A. \& Antsyfirova, G.A., 1987. The experience of stratigraphic separation of Late Pleistocene and Holocene deposits of Kalach Highland [in Russian]. Bulleten' Komissii po izucheniu Chetvertichnogo perioda 56: 45-65.

Van der Meulen, A.L., 1973. Middle Pleistocene smaller Mammals from Monte Peglia (Orvieto, Italy) with special reference to the phylogeny of Microtus (Arvicolidae, Rodentia). Quaternatia 17: 144 pp.

Velichkevich, F.Yu., 1982. Pleistocene flora of glacial regions of East-European Plain [in Russian]. Nauka i Tekhnika Press (Minsk): $208 \mathrm{pp}$. 